\title{
Marital satisfaction, job satisfaction and psychological health of secondary school teachers in Nigeria
}

\author{
C. E. Ofovwe ${ }^{1 *}$, A. N. Ofili ${ }^{2}$, O. G. Ojetu ${ }^{2}$, F. E. Okosun ${ }^{2}$ \\ ${ }^{1}$ Department of Mental Health, School of Medicine, College of Medical Sciences, University of Benin, Benin City, Nigeria; \\ *Corresponding Author: cofovwe@yahoo.com \\ ${ }^{2}$ Department of Community Health, School of Medicine, College of Medical Sciences, University of Benin, Benin City, Nigeria
}

Received 18 February 2013; revised 20 March 2013; accepted 1 April 2013

Copyright (C) 2013 C. E. Ofovwe et al. This is an open access article distributed under the Creative Commons Attribution License, which permits unrestricted use, distribution, and reproduction in any medium, provided the original work is properly cited.

\section{ABSTRACT}

Introduction: Marital satisfaction has remained a topic of great interest worldwide. Association has been postulated between marital satisfaction, job satisfaction and mental health. There is, however, a paucity of research on marital satisfaction in Nigeria, particularly in relation to job satisfaction and psychological health. Objective: The objective of this study is thus to assess the level of marital satisfaction and to explore the relationship if any between marital satisfaction, job satisfaction and mental health of secondary school teachers in Benin City, Edo State, Nigeria. Methods: A cross sectional study was conducted on teachers in secondary schools in Benin City, Nigeria. A total population of $\mathbf{3 0 0}$ teachers who had been married and teaching for at least one year were included in the study. The information required for the study were collected using a self-administered questionnaire and two standard instruments, the Index of Marital Satisfaction (IMS) and the General Health Questionnaire 28 (GHQ 28). The GHQ was used to assess the workers psychological health, while the IMS was used to assess the degree of marital satisfaction. Results: Two hundred and fifteen (82.7\%) teachers had marital satisfaction, $54(20.8 \%)$ had psychological disorder while $56(21.5 \%)$ were dissatisfied with their job. A strong association was found between marital dissatisfaction and psychological disorder $\left(X^{2}=56.826\right.$; $\mathrm{df}=1, \mathrm{P}=$ $0.0004)$. No association was found between marital dissatisfaction and job dissatisfaction. No association was also found between job dissatisfaction and psychological disorder. Conclu- sion: A high level of marital satisfaction was found in the study population. However, the strong association also found between marital dissatisfaction and psychological disorder provides empirical evidence on the need to educate married couples as well as the general public on the mental health implication of marital dissatisfaction.

Keywords: Marital Satisfaction; Job Satisfaction; Psychological Wellbeing; Teachers; Nigeria

\section{INTRODUCTION}

Marital satisfaction refers to an individual's positive assessment of his/her marital relations. A number of determinants seem to be associated with marital satisfaction amongst which are compatibility of personality, educational homogamy, religious homogamy, income level, level of education, age at marriage, age of marriage [1-4]. Hampton [5] in a phenomenal study of African American couples and their perceptions of marital longetivity found that couples who had remained married for 25 years or more claimed that marital longetivity was based on several themes, which include: God is the foundation of marriage, joint religious rituals and activities to promote intimacy, companionship/friendship, common goals and values, example for others, commitment to marriage, trust in the other person, impact of family history, satisfaction in the marriage, etc. The above themes suggest that marital stability involves a lot of effort for its sustenance. It is also assumed that the significance of marriage in an individual's life has the prospect of affecting other facets of live such as job satisfaction and psychological health. Marital satisfaction has thus remained an area of research interest due to its wide range implica- 
tions to persons involved as well as society at large.

Job satisfaction refers to the personal feelings of contentment or a compound of various attitudes, mental and emotional, which a worker has and exhibits toward his work situation [6]. Job satisfaction is defined as a pleasureable emotional state resulting from the appraisal of one's job [7], an affective reaction to one's job [8] and an attitude towards one's job [9]. Job satisfaction can be an important indicator of how employees feel about their jobs and a predictor of work behaviours such as organizational citizenship, absenteeism, and turnover [10-12], Job satisfaction can also partially mediate the relationship of personality variables and deviant work behaviours [13]. A common research finding is that job satisfaction is correlated with life satisfaction [14]. By implication, it is assumed that people who are satisfied with life tend to be satisfied with their job and people who are satisfied with their job tend to be satisfied with life. However, research has found that job satisfaction is not significantly related to life satisfaction when other variables such as non work satisfaction and core self-evaluations are taken into account [15]. In this study, attempt is made to evaluate the relationship between marital satisfaction and job satisfaction.

The Hawthorne studies (1924-1933) remain a significant landmark in the theoretical interest in job satisfaction. Other worthy contributions to the understanding of the concept of job satisfaction are attributed to the contribution of Taylor's scientific management and Maslow's theory on the hierarchy of needs. Several models have also broadened the understanding of the concept of job satisfaction. These include Edward A. Locke's Range of Affect theory which states that job satisfaction is a function of the discrepancy between whatever one wants in a job and what one has in a job. According to this theory, the value placed on a given facet of a job determines satisfaction or dissatisfaction.

The Dispositional theory Template is another important theory which suggests that innate disposition account for level of job satisfaction regardless of the job. Twin studies show that identical twins have similar levels of job satisfaction seem to support this model. The scope of the Dispositional theory is further narrowed by the Core self-evaluation Model proposed by Judge, Locke and Durban [16]. They argued that there are four core self evaluation criteria that determine ones disposition towards a job, these are self esteem, general self efficacy, locus of control and neuroticism. This model states that higher levels of self-esteem (the value one places on his/ her self) and general self-efficacy (the belief in one's own competence) lead to higher work satisfaction. Having an internal locus of control (believing one has control over her hhis own life, as opposed to outside forces having control) leads to higher job satisfaction, while lower levels of neuroticism lead to higher job satisfaction [16].

The Equity theory emphasizes fairness in social relationship as the basis for satisfaction or dissatisfaction [17, 18]. Summarily, this theory argues that if an individual thinks there is an inequality between two social groups or individuals, the person is likely to be distressed because the ratio between the input and the output are not equal. On the other hand, the two factor theory (Motivation and Hygiene Theory) by Fredrick Herzberg [17] attempts to explain satisfaction and motivation in the work place by stating that satisfaction/dissatisfaction is driven by 2 factors: motivation and hygiene factors respectively. Motivating factors are intrinsic in nature: they are those aspects of the job that enhance performance, satisfaction, achievement, recognition and promotion. Hygiene factors include aspects of the working environment such as pay, company policies and other working conditions. Although this theory has stimulated much research, the model can still not be empirically proven, it does not consider individual differences and fails to show how motivating/hygiene factors can be reliably measured.

Of current appeal is the Job Characteristics Model proposed by Hackman and Oldham [18]. The model states that there are five core job characteristics (skill variety, task identity, task significance, autonomy, and feedback) which impact three critical psychological states (experienced meaningfulness, experienced responsibility for outcomes, and knowledge of the actual results), in turn influencing work outcomes (job satisfaction, absenteeism, work motivation, etc.)

The assessment of job satisfaction in this study reflects the above stated theoretical models to a large extent. It is however difficult to state which theoretical framework best describes workers disposition categorically. It suffices to say an eclectic approach is best suited for an evaluation of this nature. The focus of the present works rest on the proposition that job satisfaction can affect marital status and vice versa owing to research claims on the association of job satisfaction with life satisfaction [14].

There is also a growing body of research findings indicating that psychopathology is intricately linked with marital functioning [19]. An understanding of this association can be traced to two perspectives (actor effects and partner effects). The first perspective assumes that a person's level of psychopathology has the potential of affecting his/her own level of relationship satisfaction. Research in favour of this view indicate that compared with individuals without a disorder, people seeking treatment for mood disorders [20,21] anxiety disorders [22, 23] and substance use disorders [24] report lower marital satisfaction The second perspective on the association between psychopathology and marital satisfaction has evaluated the association between psychopathology in 
one person and relationship satisfaction in the partner (i.e., partner effects). For example, partner effects have been studied to evaluate the perspective that there are burdens associated with being in a relationship with someone with mental health problems and that these burdens may result in lower relationship satisfaction for the partner $[25,26]$. In support of this perspective, studies have found that the presence of psychopathology in one person is associated with lower marital satisfaction in the partner $[22,27]$. The present study evaluated the psychological health of the respondents in relation to their level of marital satisfaction in consonance with the first perspective (i.e. actor effects).

\section{MATERIALS AND METHODS}

A cross sectional study was conducted among secondary teachers in secondary schools in Egor local government area in Benin City, Edo State, Nigeria between May 2004 and January 2005. Three hundred teachers who had been married for at least one year were included in the study.

The information required for the study was collected with the use of self administered questionnaires; a structured questionnaire which was used to collect information on demographic data and two standard instruments; the Index of Marital Satisfaction (IMS) designed by Walter W. Hudson [28,29] and the General health Questionnaire (GHQ 28) designed by David Goldberg [30, 31].

Index of Marital Satisfaction was used to measure the degree of marital satisfaction. The questionnaire comprise 25 questions of which 13 are positively worded while 12 are negatively worded. Respondents had to indicate on a 5 point score scale depending on what is appropriate for them. The positively worded items were scored in the reverse such that 1 was rescored as 5, 2 as 4, 3 remained as 3, 4 as 2 and 5 as 1 .

The positively worded items were $1,3,5,8,9,11,13$, $16,17,19,20,21,23$. The questionnaire adopts a Likert scoring scale which ranges from rarely or none of the time (1) A little or none of the time (2) Sometimes (3) A good part of the time (4) and Most of the time (5). After this, all the scores were summed up. The index of marital satisfaction was derived from subtracting 25 from the total score. A score below 30 was indicative of satisfaction with the relationship while a score above 30 was indicative of dissatisfaction.

The second standard instrument used was the General Health Questionnaire (GHQ 28) designed by David Goldberg. It was used to measure the psychological health of the workers in this study. It has been used in various cultural setting. Although it was initially designed to be culture specific, it has currently been used in about 38 languages with commendable psychometric variables [32]. GHQ 28 is subdivided into four subscales measuring somatic symptoms, anxiety, social dysfunction and depression. Respondents had to indicate on a four point Likert scale ranging from less than usual to much more than usual whether they have experienced any of the GHQ symptoms recently. As recommended an overall GHQ value is obtained by summing $0-0-1-1$. A score of 4 and above was an indication of having a psychiatric dysfunction. The GHQ differentiates psychotic patients as a class from non cases as a class.

The questionnaires were self administered. They were personally distributed by the researchers. A pre testing of the instruments was carried out two weeks prior to the actual study in Oredo local government area of Edo State. Of the 105 government approved schools in Egor local government area, 14 schools comprising 7 private and 7 public schools were involved in the study. Ethical considerations were given top priority; a letter of approval from the Chief Inspector of Education of the local government area was obtained before the commencement of the study.

Data was subjected to both descriptive and analytical statistics. Responses were expressed as either percentages or proportions. Chi square test was used in assessing Associations between variables was assessed with the Chi square test. $\mathrm{P}$ value was considered significant at the 0.05 level of significance.

\section{RESULTS}

Of the 300 questionnaires administered in the study, $40(13.3 \%)$ were lost to non-response, thus the total study population comprise 260 respondents. The respondents were of varied socio-demographic characteristics. The age of the respondents ranged from 20 years to 64 years, with a mean age of $38.6 \pm 8.3$ years. $169(65 \%)$ of the respondents were females while 91 were males. The respondents were predominately Christians, however some were Muslims while a few belonged to traditional religious bodies. Duration of marriage of respondents ranged from 1 year to 35 years, with the highest frequency between 1 - 10 years $(154(59.2 \%))$ and the lowest frequency between 26 - 35 years $(12(4.6 \%)) .62$ $(23.9 \%)$ of the respondents had National Certificate of Education, 137 (52.7\%) were University graduates and $61(23.5 \%)$ had either a Masters degree or a higher degree (Table 1).

$215(82.7 \%)$ of the respondents were satisfied with their marriage compared to $45(17.3 \%)$ who were dissatisfied. No statistical significant association was found between marital satisfaction and job satisfaction. 128 $(82.6 \%)$ were both satisfied with their marriage and their jobs while $44(78.6 \%)$ were dissatisfied with their mar- 
Table 1. Demographic characteristics of respondents.

\begin{tabular}{lcc}
\hline Variable & Frequency & $\%$ \\
\hline Age & 6 & $(2.3)$ \\
$20-24$ & 30 & $(11.5)$ \\
$25-29$ & 56 & $(21.5)$ \\
$30-34$ & 48 & $(18.5)$ \\
$35-39$ & 56 & $(21.5)$ \\
$40-44$ & 40 & $(15.4)$ \\
$45-49$ & 15 & $(5.8)$ \\
$50-54$ & 8 & $(3.1)$ \\
$55-59$ & 1 & $(0.4)$ \\
$60-64$ & & \\
Gender & 91 \\
Male & 169 \\
Female & & $(35)$ \\
Level of Education & 63 \\
National Cert of Education (NCE) & 137 \\
Bachelor of Sci/Edu (B.Sc/ B.Ed) & 46 \\
Masters degree & 14 & $(52.7)$ \\
Others & & $(17.7)$ \\
\hline
\end{tabular}

riage as well as with their jobs (Table 2).

An assessment of the respondents level of job satisfaction showed that $155(59.6 \%)$ were satisfied, $56(21.5 \%)$ were dissatisfied while $49(18.9 \%)$ were undecided about the assessment of their jobs. A number of reasons were given for job satisfaction, these included love for the profession $85(54.8 \%)$, reasonable salary $26(16.8 \%)$, favourable working conditions $19(12.2 \%)$ having time for other activities $16(10.3 \%)$ among others. Conversely, the 56 respondents who were not satisfied stated reasons which include poor salary $38(67.9 \%)$, poor working condition $10(17.9 \%)$ and lack of incentives $8(14.2 \%)$ (Tables 3 and 4).

The psychological assessment showed that $206(79.2 \%)$ of the respondents had a GHQ score of less than 4 indicating the absence of psychiatric disorder while 54 $(20.8 \%)$ had a score of 4 or above which is indicative of presence of a psychiatric disorder. Although there was no statistically significant difference between males and females on the GHQ scores, a statistically significant association $\left(\mathrm{X}^{2}=43.31 \mathrm{df}=1, \mathrm{P}<0.05\right)$ was found between marital satisfaction and psychological well being. One hundred and eighty-nine $(87.9 \%)$ respondents who were satisfied with their marriage had a GHQ score of less than 4 while $28(60 \%)$ of respondents with marital dissatisfaction had a GHQ score of more than 4 (Tables 5 and 6).
Table 2. Relationship between marital satisfaction and job satisfaction.

\begin{tabular}{lccc}
\hline & $\begin{array}{c}\text { Marital } \\
\text { Satisfaction }\end{array}$ & $\begin{array}{c}\text { Marital } \\
\text { Dissatisfaction }\end{array}$ & Total \\
\hline Job Satisfaction & $128(82.6 \%)$ & $27(17.43 \%)$ & $155(100 \%)$ \\
Job Dissatisfaction & $44(78.6 \%)$ & $12(21.4 \%)$ & $56(100 \%)$ \\
Total & $172(81.5 \%)$ & $39(18.5 \%)$ & $211(100 \%)^{*}$ \\
\hline${ }^{*} 49$ respondents were undecided concerning their job satisfaction status. $\mathrm{X}^{2}$ \\
$=0.435, \mathrm{df}=1, \mathrm{P}=0.508$.
\end{tabular}

Table 3. Relationship between marital satisfaction and GHQ.

\begin{tabular}{lccc}
\hline $\begin{array}{l}\text { Psychological } \\
\text { Disorder }\end{array}$ & $\begin{array}{c}\text { Marital } \\
\text { Satisfaction }\end{array}$ & $\begin{array}{c}\text { Marital } \\
\text { Dissatisfaction }\end{array}$ & Total \\
\hline Absent: GHQ $\leq 4$ & $189(87.9 \%)$ & $17(40 \%)$ & $206(79.6 \%)$ \\
Present: GHQ $\geq 4$ & $26(12.1 \%)$ & $28(60 \%)$ & $54(21.4 \%)$ \\
Total & $215(100 \%)$ & $45(100 \%)$ & $260(100 \%)$ \\
\hline
\end{tabular}

$\mathrm{X}^{2}=56.83, \mathrm{df}=1, \mathrm{P}=0.000$

Table 4. Relationship between GHQ and job satisfaction.

\begin{tabular}{lccc}
\hline $\begin{array}{l}\text { Psychological } \\
\text { Disorder }\end{array}$ & Job Satisfied & Job Disatisfied & Total \\
\hline Absent: GHQ $\leq 4$ & $127(81.1 \%)$ & $40(71.4 \%)$ & $167(79.1 \%)$ \\
Present: GHQ $\geq 4$ & $28(18.1 \%)$ & $16(28.6 \%)$ & $44(20.9 \%)$ \\
Total & $155(100 \%)$ & $56(100 \%)$ & $211(100 \%)^{*}$ \\
\hline
\end{tabular}

${ }^{*} 49$ respondents were undecided concerning their job satisfaction status; $\mathrm{X}^{2}$ $=2.75, \mathrm{df}=1, \mathrm{P}=0.09$.

\section{DISCUSSION}

A greater proportion of the respondents being female $(65 \%)$ is rarely surprising as teaching is generally perceived as "a woman's job" owing to the "assumed ease of the work schedule" compared to other jobs like engineering, medicine or being in the banking sector. This assumption is not unrelated to gender issues. According to Okojie [33], gender is used to distinguish between the two categories "masculine" and "feminine". It is a social construct which describes the social differences and relations between girls and boys, women and men that are learned through the socialization process. Williams [34] argues that gender issues results in males and females being valued differently and their having unequal opportunities and life chances .

A total of two hundred and fifteen (82.7\%) respondents were satisfied with their marriage. This seems remarkable. A number of determinants like religious, educational and tribal homogeneity could be attributed to the high level of marital satisfaction among the respondents. For instance more educated women have been reported to be more prepared to enter marriage and promote stability of the relationship [35]. It is also reported that women's economic contribution can enhance marital stability [35]. These variables however require a more stringent 
Table 5. Relationship between marital satisfaction and gender.

\begin{tabular}{cccc}
\hline Gender & $\begin{array}{c}\text { Marital } \\
\text { Satisfaction }\end{array}$ & $\begin{array}{c}\text { Marital } \\
\text { Dissatisfaction }\end{array}$ & Total \\
\hline Male & $76(83.5 \%)$ & $15(16.5 \%)$ & $91(100 \%)$ \\
Female & $139(82.8 \%)$ & $30(17.2 \%)$ & $169(100 \%)$ \\
Total & $215(83.1 \%)$ & $45(16.9 \%)$ & $260(100 \%)$ \\
\hline $\mathrm{X}^{2}=0.066, \mathrm{df}=1$. & & &
\end{tabular}

Table 6. Relationship between GHQ and gender.

\begin{tabular}{cccc}
\hline GHQ score & Male & Female & Total \\
\hline GHQ $<4$ & $70(76.9 \%)$ & $136(80.6 \%)$ & $206(79.2 \%)$ \\
GHQ $\geq 4$ & $21(23.9 \%)$ & $33(19.4 \%)$ & $54(21.8 \%)$ \\
Total & $91(100 \%)$ & $169(100 \%)$ & $260(100 \%)$ \\
\hline
\end{tabular}

$\mathrm{X}^{2}=0.453, \mathrm{P}=0.501$.

assessment for an association to be established. It is however worthy of note, that in a developing country like Nigeria, marriage is honoured highly and the divorced and separated are looked upon with disdain as failures. This premise could promote a denial of an unsatisfactory marriage for social desirability status and increase a tendency to project the marriage as satisfactory.

A statistically significant association was found between marital satisfaction and psychological functioning. $189(87.9 \%)$ of the respondents who were satisfied with their marriage had a GHQ score of less than 4 as compared to $28(60 \%)$ with a score of more than 4 who were dissatisfied with their marriage. In other words the supposed absence of psychological dysfunction enhances marital satisfaction and conversely the presence of psychological dysfunction will result in marital dissatisfaction, this supports the "actor effect" perspective [20-25]. However, in agreement with Whisman, Uebelacker \& Weinstock [36] unless data from both individuals are included, one cannot determine to what extent the observed associations between measures of psychopathology and marital satisfaction are due to one partner's own mental health versus the other partner's mental health. Nonetheless, the need to encourage teachers to pursue habits and attitudes that promote marital satisfaction through periodic seminars, counseling sessions etc cannot be overemphasized. The significant role teachers play in National development makes this imperative.

As much as $59.7 \%$ of the respondents were satisfied with their jobs. There was however no significant association found between marital satisfaction and job satisfaction. Contrary to research reports [14] our findings failed to find a significant association between marital satisfaction and job satisfaction. Our findings are however in agreement with Rode's findings [15] which argue that job satisfaction may not be significantly related to life satisfaction when other variables such as non work satisfaction and core self-evaluations are taken into account. Though not explicitly specified the authors are of the opinion that marital satisfaction can be considered as a "non work satisfaction and a core self evaluation".

None of the aforementioned theoretical models singly explained the respondents job satisfaction, rather as earlier noted an eclectic approach seem more beneficial in this regard. Love for the profession was the most given reason, for job satisfaction. On the other hand, those who were dissatisfied gave reasons such as poor salary, unfavourable working condition, etc. It could be argued that an intrinsic motivation towards the job as exhibited by those who were satisfied seem to blur the shortcomings of the job enumerated by the dissatisfied group. Taken further, it can also be argued that those who are not intrinsically motivated are more likely to have reasons to dislike the job. Despite this supposed interface, there is the need to improve the work conditions as identified to increase morale.

Interestingly there was no statistical relationship found between job satisfaction and psychological well being. A majority of job satisfied respondents as well as job dissatisfied respondents had comparable proportions in GHQ scores indicative of the absence of pathology. It is thus probable that their respective assessment of their jobs had no psychological underpinnings.

\section{REFERENCES}

[1] Tucker, M.W. and Grady, K.E. (1991) Effects of physical attractiveness, intelligence, age of marriage and cohabitation on the perception of marital satisfaction. The Journal of Social Psychology, 132, 253-269. doi:10.1080/00224545.1991.9713848

[2] Cliford, R. and Begstan, B. (1979) Measuring marital satisfaction in three generations: Positive and negative dimensions. Journal of Marriage and Family, 387-389.

[3] Pickfold, J.H., Signori, E.I., John, H. and Rempel, H. (1966) Similar or related personality traits as a factor in marital happiness. Journal of Marriage and Family, 28, 190-192. doi: $10.2307 / 349280$

[4] Heatton, T.B. and Pratt, E.L. (1990) The effects of religious hamogamy on marital satisfaction and stability. Journal of Family Issues, 11, 191-207. doi: $10.1177 / 019251390011002005$

[5] Hampton, A.V. (2007) A phenomenal study of Christian African-American Couples and their perceptions of longetivity. Ph.D. Thesis, Regent University, Virginia Beach.

[6] Ajayi, K.A. (1983) The relationship between job satisfaction and productivity among junior workers in a service oriented enterprise. Psychology for Everyday Living, 2, 133.

[7] Locke, A.P. and Weiss, H.M. (2001) 1976 cited in brief, organizational behavior: Affect in the workplace. Annual Review of Psychology, 53, 279-307.

[8] Cranny, Smith \& Stone, 1992 cited in Weiss, H. M. (2002) 
Deconstructing job satisfaction: Separating evaluations, beliefs and affective experiences. Human Resource Management Review, 12, 173-194.

[9] Brief, 1998 cited in Weiss, H. M. (2002) Deconstructing job satisfaction: Separating evaluations, beliefs and affective experiences. Human Resource Management Review, 12, 173-194.

[10] Organ, D.W. and Ryan, K. (1995) A meta-analytic review of attitudinal and dispositional predictors of organizational citizenship behavior. Personnel Psychology, 48, 775-802. doi:10.1111/j.1744-6570.1995.tb01781.x

[11] Wegge, J., Schmidt, K., Parkes, C. and van Dick, K. (2007) "Taking a sickie": Job satisfaction and job involvement as interactive predictors of absenteeism in a public organization. Journal of Occupational and Organizational Psychology, 80, 77-89. doi:10.1348/096317906X99371

[12] Saari, L.M. and Judge, T.A. (2004) Employee attitudes and job satisfaction. Human Resource Management, 43, 395-407. doi:10.1002/hrm.20032

[13] Mount, M., Ilies, R. and Johnson, E. (2006) Relationship of personality traits and counterproductive work behaviors: The mediating effects of job satisfaction. Personnel Psychology, 59, 591-622. doi:10.1111/j.1744-6570.2006.00048.x

[14] Rain, J.S., Lane, I.M. and Steiner, D.D. (1991) A current look at the job satisfaction/life satisfaction relationship: Review and future considerations. Human Relations, 44, 287-307. doi:10.1177/001872679104400305

[15] Rode, J.C. (2004) Job satisfaction and life satisfaction revisited: A longitudinal test of an integrated model. $\mathrm{Hu}-$ man Relations, 57, 1205-1230. doi: $10.1177 / 0018726704047143$

[16] Judge, T.A., Locke, E.A. and Durham, C.C. (1997) The dispositional causes of job satisfaction: A core evaluations approach. Research in Organizational Behavior, 19, 151-188.

[17] Walster, E., Berscheid, E. and Walster, G.W. (1973) New directions in equity research. Journal of Personality and Social Psychology, 25, 151-176. doi:10.1037/h0033967

[18] Huseman, R., Hatfield, J. and Miles, E. (1987) A new perspective on equity theory: The equity sensitivity construct. Academy of Management Review, 12, 232-234.

[19] Whisman, M.A. and Uebelacker, L.A. (2003) Comorbidity of relationship distress and mental and physical health problems. In: Snyder, D.K. and Whisman, M.A., Eds., Treating Difficult Couples: Helping Clients with Coexisting Mental and Relationship Disorders, Guilford Press, New York, 3-26.

[20] Bauserman, S.A.K., Arias, I. and Craighead, W.E. (1995) Marital attributions in spouses of depressed patients. Journal of Psychopathology and Behavioral Assessment, 17, 231-249. doi:10.1007/BF02229300

[21] Vega, B.R., Bayon, C., Franco, B., Canas, F., Graell, M. and Salvador, M. (1993) Parental rearing and intimate relations in women's depression. Acta Psychiatrica Scan- dinavica, 88, 193-197. doi:10.1111/j.1600-0447.1993.tb03438.x

[22] Arrindell, W.A. and Emmelkamp, P.M.G. (1986) Marital adjustment, intimacy, and needs in female agoraphobics and their partners: A controlled study. British Journal of Psychiatry, 149, 592-602. doi:10.1192/bjp.149.5.592

[23] Chambless, D.L., Fauerbach, J.A., Floyd, F.J., Wilson, K.A., Remen, A.L. and Renneberg, B. (2002) Marital interaction of agoraphobic women: A controlled, behavioral observation study. Journal of Abnormal Psychology, 111, 502-512. doi:10.1037/0021-843X.111.3.502

[24] Fals-Stewart, W., Birchler, G.R. and O'Farrell, T.J. (1999) Drug-abusing patients and their intimate partners: Dyadic adjustment, relationship stability, and substance use. Journal of Abnormal Psychology, 108, 11-23. doi:10.1037/0021-843X.108.1.11

[25] Chakrabarti, S., Kulhara, P. and Verma, S.K. (1993) The pattern of burden in families of neurotic patients. Social Psychiatry and Psychiatric Epidemiology, 28, 172-177. doi:10.1007/BF00797319

[26] Coyne, J.C., Kessler, R.C., Tal, M., Turnbull, J., Wortman, C.B. and Greden, J.F. (1987) Living with a depressed person. Journal of Consulting and Clinical Psychology, 55, 347-352. doi:10.1037/0022-006X.55.3.347

[27] Hudson, W.W. (1992) Index of marital satisfaction tempe, AZ, Walmyr Publishing Co.

[28] Cheug, P.P. and Hudson, W.W. (1982) Assessment of marital discord in social work practice: A revalidation of the index of marital satisfaction. Journal of Social Service Research, 5, 101-118. doi:10.1300/J079v05n01 07

[29] Goldberg, D.P. and William, P.A. (1988) User's guide to the general health questionnaire. NFER-NELSON Publishers, Windsor, 4-5.

[30] Goldberg, D.P. (1992) The detection of psychiatric illness by Questionnaire. Oxford University Press, Oxford.

[31] Goldberg, D.P. (1978) Manual of the general health questionnaire. NFER-NELSON Publishers, Windsor, 8.

[32] Okojie, C.E.E. (2011) Achieving gender equality and women's empowerment in Nigeria: Should women wait in hope or expectation? Inaugural Lecture Series 120, University of Benin, Benin, 1.

[33] Williams, M. (2005) A simple-gender aware framework for research and advocacy on trade agreements and trade policy. Symposium on Gender and Trade Liberalization: Global-Local Processes and Gendered Impacts in Asia and Beyond, 22-23 August 2005.

[34] Adesanya, S.A. (2002) Correlates of marital stability among couples in South Western Nigeria. Unpublished Ph.D. Thesis, University of Ado-Ekiti, Ado-Ekiti.

[35] Whisman, M.A., Uebelacker, L.A. and Weinstock, L.M. (2004) Psychopathology and marital satisfaction: The importance of evaluating both partners. Journal of Consulting and Clinical Psychology, 72, 830-838. 